\title{
Substitution of milk allergen ingredient by blood plasma powder in custard with different
} sweeteners

\author{
TAMÁS CSURKA* ㅁ, FANNI SZÜCS, BARBARA CSEHI, \\ LÁSZLÓ FERENC FRIEDRICH and KLÁRA PÁSZTOR-HUSZÁR
}

Department of Livestock Products and Food Preservation Technology, Institute of Food Science and Technology, Hungarian University of Agriculture and Life Sciences, Ménesi str. 43-45, H-1118, Budapest, Hungary

\section{CONFERENCE FULL PAPER}

Received: June 8, 2021 - Accepted: August 6, 2021

Published online: August 27, 2021

(C) 2021 The Author(s)

\begin{abstract}
Animal blood is a by-product, which can be utilized in a value-adding way instead of being wasted. Allergen substitution is a good possibility especially for a substance that is difficult to substitute, such as milk. Blood plasma is a fluid with high protein content without blood (iron) taste and colour, so it is similar to milk in several ways. While investigating the substitution of milk, it is advisable to investigate the substitution of sugar as well because a lot of consumers who exclude milk from their diet find the glycaemic index and energy content of foods important. The investigated model food is a simple, homogeneous matrix: vanilla custard with milk and with and without sugar and vanilla custard with blood plasma and with and without sugar. Colour, $\mathrm{pH}$ and rheological attributes of custard sample groups were measured. According to the results the used protein source as well as sweetener significantly determine the colour, $\mathrm{pH}$ and texture of the final product. However, colour and $\mathrm{pH}$ are easy to change with other components (food colours, acidity regulators) and the effect of milk and sugar substitution on rheological attributes might not be possible to detect without instrumental analysis.
\end{abstract}

\section{KEYWORDS}

allergen substitution, animal blood, animal by-product, product development, sustainability

*Corresponding author. E-mail: csurka.tamas@uni-mate.hu, csurkatamas@gmail.com 


\section{INTRODUCTION}

Allergen substitution and fight against global obesity are in the focus of media and literature.

According to the biological definition, milk is a liquid, which is produced by mammals, and which is serving the newborns as food and contains all nutrients newborns need for development (Spreer, 2017). Thus, it is very hard to substitute milk as an ingredient in foods. But unfortunately, milk is an allergenic food and food ingredient as well (Goldman et al., 1963).

Milk contains on average 3.2\% protein, whose main fractions are caseins (82.65\%: $30.80 \%$ $\alpha_{\mathrm{S} 1}$-casein, $7.50 \% \alpha_{\mathrm{S} 2}$-casein, $44.35 \% \beta+\kappa$-casein in proteins) and whey proteins $(17.35 \%$ in proteins) (Ceballos et al., 2009). Bovine blood plasma contains $7.9 \%$ protein, whose main fractions are albumins ( $41.77 \%$ in proteins), immune-globulins, $\alpha$ - and $\beta$-globulins $(53.17 \%$ in proteins) and fibrinogen (5.06\% in proteins) (Halliday, 1975; Howell and Lawrie, 1983). It is interesting to compare the amino acid composition of these different protein sources to observe their nutritional value. The comparison of the amino acid composition of these two materials can be seen in Table 1. Amino acid composition of milk is more balanced for the human body. It is interesting that the ratio of amino acids which contain sulphur is the opposite in the two different protein sources.

The utilization of blood is important, not only for allergen substitution but also for sustainability. Three-five percent of an animal's whole weight is blood, which can be produced during bloodletting after slaughtering (Halliday, 1975). This high amount of blood is mostly annihilated instead of value-adding further-processing because too few blood-based food products are widespread and popular in Europe. Implementing the technical conditions of

Table 1. Amino acid composition of bovine blood plasma and cow milk in mass percent per total amino acid content (Ceballos et al., 2009; Duarte et al., 1999)

\begin{tabular}{lcc}
\hline Amino acid & $\begin{array}{c}\text { Bovine blood plasma } \\
{[\mathrm{mg} / 100 \text { amino acid }]}\end{array}$ & $\begin{array}{c}\text { Cow milk } \\
{[\mathrm{mg} / 100 \text { amino acid }]}\end{array}$ \\
\hline Val & 6.73 & 5.24 \\
Ile & 3.35 & 4.54 \\
Leu & 9.34 & 9.44 \\
Thr & 6.6 & 4.11 \\
Cys & 3.36 & 0.82 \\
Met & 0.86 & 2.48 \\
Tyr & 4.87 & 5.67 \\
Phe & 5.16 & 4.73 \\
His & 9.94 & 3.3 \\
Lys & 4.18 & 8.96 \\
Try & 7.47 & no data \\
Asp & 1.18 & 7.6 \\
Ser & 9.8 & 5.24 \\
Glu & 6.67 & 19.66 \\
Pro & 4.74 & 8.99 \\
Gly & 3.39 & 1.75 \\
Ala & 5 & 3.41 \\
Arg & 3.3 & 4.06 \\
\hline
\end{tabular}


collecting blood for human consumption, which are required according to the Regulation 853/ 2004/EC, is expensive for smaller slaughterhouses. So, annihilation is necessary if the blood product cannot be sold according to the Directive 91/271/EEC and Commission Directive 98/ 15/EC (chemical oxygen demand maximum: $125 \mathrm{mg} \mathrm{L}^{-1}$ ). Chemical oxygen demand of blood is about $400 \mathrm{~g} \mathrm{~L}^{-1}$ and the biological oxygen demand of blood is about $200 \mathrm{~g} \mathrm{~L}^{-1}$ (Ofori and Hsieh, 2011). Thus, producing functional foods with blood or blood fractions for a special consumer group is a good opportunity. There were already investigations in the topic of substituting egg (Caldironi and Ockerman, 1982; Raeker and Johnson, 1995).

Custard is a perfect test matrix for the investigation of substituting milk by blood plasma, because it is simple to handle and has only a few ingredients. Nearly all foods are colloid systems. Custard dessert consists of two phases: 1.) a continuous aqueous phase containing starch and/or carrageenan and 2.) a dispersed phase of oil. The role of proteins is to stabilize the dispersed phase (Wijk et al., 2003). Thus, firstly the effect of blood plasma and milk proteins can be considered through texture properties. The first factor of this research which was investigated was the protein depending on the raw material: 1.) milk and 2.) blood plasma.

A lot of consumers who exclude milk from their diet find the glycaemic index and energy content of foods important. Because of this, the type of sweetener material was the second factor in this research. In this research, sucrose and sugar alcohols (xylitol and erythritol) were investigated, because these are the most widely used sweeteners in custards. Xylitol is a polyalcohol, which is marked with 'E 967' according to the Regulation (EC) No 1333/2008 of the European Parliament and of the Council on food additives, and it has $2.4 \mathrm{kcal} \mathrm{g}^{-1}$ energy content, 7 glycaemic index and 0.4 sweetening value (Sweetening value of sucrose is 1 ). It does not cause tooth decay, but it has a laxative effect in excessive amounts (Melaja and Hamalainen, 1977). Erythritol is marked with ' $\mathrm{E} 968$ ', has $0.2 \mathrm{kcal} \mathrm{g}^{-1}$ energy content, 0 glycaemic index and 0.6-0.8 sweetening value. It extends the shelf-life of bakery products, but there is a loss of the sweetening value above $160^{\circ} \mathrm{C}$ (De Cock and Bechert, 2002). There is a popular mixture of erythritol and xylitol in 55:45 ratio, which is easy to use, because its sweetening effect is equal to that of common crystal sugar (sucrose).

The aim of this study was to investigate the effect of milk and blood plasma in the presence of different sweeteners (sugar and sugar alcohols) on instrumentally measured sensory attributes like colour and texture as well as techno-functional attributes measured by instrumental methods.

\section{MATERIALS AND METHODS}

\section{Materials}

To substitute allergenic milk protein by blood plasma protein, an adequate and homogeneous sample matrix had to be found: this was the custard. At the same time, fat content of milk (2.8\%) was also substituted, by sunflower oil, which does not have an unusual flavour, for developing a similar sample matrix in the case of each examined protein source. Overplus water content of milk was replaced by drinking water. Blood plasma was made from an easy-to-handle plasma powder by diluting it to the same protein content that the milk had. Thus, the protein content of custard made with blood plasma powder was closely matching that of milk. Raw material specifications and food nutrition database (USDA, 2018) were used for calculating the recipe. 
Table 2. Ingredients' mass [g] in recipes of different investigated products

\begin{tabular}{lcccc}
\hline Ingredients & $\begin{array}{c}\text { Vanilla custard } \\
\text { with milk and } \\
\text { sugar }\end{array}$ & $\begin{array}{c}\text { Vanilla custard } \\
\text { with milk and } \\
\text { sweeteners }\end{array}$ & $\begin{array}{c}\text { Vanilla custard } \\
\text { with blood plasma } \\
\text { and sugar }\end{array}$ & $\begin{array}{c}\text { Vanilla custard } \\
\text { with blood plasma } \\
\text { and sweeteners }\end{array}$ \\
\hline $\begin{array}{l}\text { Modified corn } \\
\text { starch (g) }\end{array}$ & 5 & 5 & 5 & 5 \\
$\begin{array}{l}\text { Milk with 2.8\% fat } \\
\text { content (g) }\end{array}$ & 100 & 100 & - & - \\
$\begin{array}{l}\text { Vanilla aroma (g) } \\
\text { Blood plasma } \\
\text { powder (g) }\end{array}$ & 1 & 1 & 1 & 1 \\
$\begin{array}{l}\text { Water (g) } \\
\text { Sunflower oil (g) }\end{array}$ & - & - & 4.3 & 4.3 \\
$\begin{array}{l}\text { Crystal sugar (g) } \\
\text { Sweetener mix (g) }\end{array}$ & - & - & 92.9 & 92.9 \\
\hline
\end{tabular}

Plasma powder 70B (Sonac Burgum B.V., Netherlands) was used. The used sweetener mix was made of erythritol:xylitol in 55:45 ratio (Gorky és Zentai Kft., Hungary). Modified corn starch was used for texture developing. Recipes are shown in Table 2.

Samples were produced according to the following procedure: Dry powdered ingredients were mixed well. Then dry ingredients were mixed with the milk or water while being heated. Fluids were heated to the gelatinization temperature, then to the boiling temperature, while stirring continuously. Samples were boiled for $1 \mathrm{~min}$.

\section{Methods}

Colour measurement. Minolta CR-400 (Konica Minolta, INC., Japan) chroma meter was used for the reflection colour measurement. The measurement is based on the fact that any colour can be generated by the mixture of three defined by the light wavelength. The ratio of these three different wavelength lights are plotted in a coordinate system called CIELAB colour space. The colour coordinates can be coded by numbers making colours analysable.

The instrument was calibrated with a standard white etalon. Each sample was measured three times. Measured attributes were the following: redness/greenness ( $\left.\mathrm{a}^{*}\right)$, yellowness/blueness $\left(b^{*}\right)$ and brightness $\left(\mathrm{L}^{*}\right)$. Total colour difference was calculated according to the following equation:

$$
\Delta E_{a b}^{*}=\sqrt[2]{\left(\Delta L^{*}\right)^{2}+\left(\Delta a^{*}\right)^{2}+\left(\Delta b^{*}\right)^{2}}
$$

where differences are calculated between means of different sample groups: $\Delta L^{*}=L_{1}^{*}-L_{2}^{*}$, $\Delta a^{*}=a_{1}^{*}-a_{2}^{*}, \Delta b^{*}=b_{1}^{*}-b_{2}^{*}$ (Dawson and Acton, 2018).

pH measurement. Voltcraft PHT-02 ATC pH stick (Voltcraft ${ }^{\circledR}$, Germany) pH meter was used for $\mathrm{pH}$ measurement. The principle of $\mathrm{pH}$ sticks operation is based on electronic differentiation between a referent electrode with a stable value and a $\mathrm{pH}$-sensitive electrode in a fluid with any standard redox potential. Sample $\mathrm{pH}$ is calculated from the potential difference according to a 
linear correlation. The device was calibrated before each measurement series with two standard buffers. Each sample were measured three times.

Rheological measurement. Anton-Paar Physica MCR 91 (Anton-Paar GmbH, Austria) viscometer was used for rheological measurements. The behaviour of samples (apparent viscosity - shear rate function) was measured under variable shear stress with concentric cylinders (CC27) and Couette type method, in which the sample holder cylinder is standing, and the inner cylinder is rotating. Samples were tempered to $25^{\circ} \mathrm{C}$. Two $\times$ thirty-one data were collected during one measurement run. The RPM of the inner cylinder varied between 1 and $1,000 \mathrm{~min}^{-1}$. The outcome of the measurement was a flow curve, to which a model was fitted. Each sample group was measured six time. This model can define the rheological behaviour of the samples. The flow behaviour of all samples could be approximated by the Herschel-Bulkley model that considers the following parameters: shear stress $(\tau)$, theoretical yield point $\left(\tau_{0}\right)$, deformation speed $(\gamma)$, consistency index $(\mathrm{C})$ and power exponent $(\mathrm{p})$. A new shear rate was calculated from these parameters and this new shear rate validates the compliance of the model. The determination coefficient $\left(\mathrm{R}^{2}\right)$ that represents the explained variance rate indicated a highly significant model with its value over 0.99 in the case of each sample. Solver extension of Microsoft Excel 365 version: 2010 (build: 13328.20356) software was used for fitting and verification of the model. Herschel-Bulkley model can be described by the following equation (Mezger, 2006):

$$
\tau=\tau_{0}+C \times \gamma^{p} .
$$

\section{Statistical analysis}

Measurement results were evaluated by IBM SPSS statistic v25 (IBM Corp., Armonk, NY) and Microsoft Excel 365 version: 2010 (build: 13328.20356) software. To detect the effect of protein ingredient and sweeteners on rheological parameters, multivariate analysis of variance (MANOVA) was carried out, that can compare the means of different sample groups of related variables. According to Levene's test, the homogeneity of variances was slightly violated $(P<0.05)$. The normality of residuals was checked by Shapiro-Wilk test $(P>0.05)$. The value of the unexplained variance rate (Wilks's lambda) was evaluated. The homogeneous groups were separated by Tukey post hoc test.

\section{RESULTS AND DISCUSSION}

Colour of different sample groups was similar but distinguishable. Difference was clearly visible to the naked eye. Means of colour parameters are shown in Table 3 and total colour difference is shown in Table 4. Lightness and redness-greenness of these milk custards were similar to results from other studies (Salami et al., 2019; Térrega et al., 2004), but results of blood plasma custard samples were different.

Value of $\mathrm{pH}$ may generally have an effect on the texture because of the relation between the water holding capacity of proteins and distance from the isoelectric point. So, $\mathrm{pH}$ was considered during the evaluation of results. Values of different sample groups were significantly different. This have been caused by the more alkaline attribute of plasma proteins and sugar alcohols than milk proteins and sucrose. Table 5 shows $\mathrm{pH}$ values. The $\mathrm{pH}$ results of milk 
Table 3. Means of colour parameters $\left(^{*}-\right.$ redness-greenness colour parameter $[-], b^{*}-$ yellownessblueness colour parameter $[-], \mathrm{L}^{*}$ - brightness colour parameter $\left.[-]\right)$ of different measured sample groups

\begin{tabular}{lcccr}
\hline Protein source & Sweetener & $\mathrm{L}^{*}$ & $\mathrm{a}^{*}$ & $\mathrm{~b}^{*}$ \\
\hline Blood plasma & Sugar & $60.25 \pm 0.77$ & $-0.68 \pm 0.14$ & $9.61 \pm 0.20$ \\
Blood plasma & Sweetener & $45.08 \pm 0.62$ & $-1.06 \pm 0.27$ & $6.22 \pm 0.43$ \\
Milk & Sugar & $80.13 \pm 1.10$ & $-4.13 \pm 0.11$ & $4.15 \pm 0.17$ \\
Milk & Sweetener & $79.62 \pm 1.11$ & $-3.71 \pm 0.37$ & $6.1 \pm 0.38$ \\
\hline
\end{tabular}

Table 4. Total colour differences $\left(\Delta E^{*}-\right.$ total colour difference $\left.[-]\right)$ of different measured sample groups (Darker red colour marks higher difference)

\begin{tabular}{|l||c|c|c|c|}
\hline & $\begin{array}{l}\text { Vanilla custard with } \\
\text { milk and sugar }\end{array}$ & $\begin{array}{l}\text { Vanilla custard with } \\
\text { milk and sweeteners }\end{array}$ & $\begin{array}{l}\text { Vanilla custard with } \\
\text { blood plasma and } \\
\text { sugar }\end{array}$ & $\begin{array}{l}\text { Vanilla custard with } \\
\text { blood plasma and } \\
\text { sweeteners }\end{array}$ \\
\hline $\begin{array}{l}\text { Vanilla custard } \\
\text { with milk and } \\
\text { sugar }\end{array}$ & 0.00 & $2.06 \pm 0.26$ & $20.90 \pm 0.51$ & $35.25 \pm 0.33$ \\
\hline $\begin{array}{l}\text { Vanilla custard } \\
\text { with milk and } \\
\text { sweeteners }\end{array}$ & $2.06 \pm 0.26$ & 0.00 & $19.92 \pm 0.50$ & $34.64 \pm 0.41$ \\
\hline $\begin{array}{l}\text { Vanilla custard } \\
\text { with blood plasma } \\
\text { and sugar }\end{array}$ & $20.90 \pm 0.51$ & $19.92 \pm 0.50$ & 0.00 & $15.55 \pm 0.20$ \\
\hline $\begin{array}{l}\text { Vanilla custard } \\
\text { with blood plasma } \\
\text { and sweeteners }\end{array}$ & $35.25 \pm 0.33$ & $34.64 \pm 0.41$ & $15.55 \pm 0.20$ & 0.00 \\
\hline
\end{tabular}

Table 5. Means of $\mathrm{pH}$ value [-] of different measured sample groups

\begin{tabular}{lcc}
\hline Protein source & Sweetener & $\mathrm{pH}$ \\
\hline Blood plasma & Sugar & $7.88 \pm 0.02$ \\
Blood plasma & Sweetener & $8.34 \pm 0.03$ \\
Milk & Sugar & $6.33 \pm 0.02$ \\
Milk & Sweetener & $6.37 \pm 0.02$ \\
\hline
\end{tabular}

custards were similar to the literature (Bassen et al., 1989; Kebede and Ashenafi. 2010; Park et al., 2017).

Rheological behaviour of all custard sample groups was measured in two different ways. The clotted texture and the skin on the surface were broken during first measurement. Then samples from each sample group were stirred and measured again. Thereby, the clotted custard status and the stirred custard status could be investigated as well. The overall MANOVA result was highly significant for protein source, sweetener as well as the two-way interaction of these two 
factors (Wilks' Lambda: 0.001; 0.001; 0.004 all with $P<0.001$ ) in the case of clotted custard. In the case of the second measurement cycle, i.e., in the case of stirred custard, the overall MANOVA result was also highly significant for protein source, sweetener as well as the two-way interaction of these two factors (Wilks' Lambda: 0.002; 0.009; 0.007 all with $P<0.001$ ). In the case of stirred custard values of Wilks' Lambda were slightly higher but these indicate a strong effect of factors, too. Means of rheological parameters are shown in Table 6. Texture of different sample groups was different, but a sensory test might not be able to detect it based on our observation (small nominal differences). Rheological parameter results of milk custards and the

Table 6. Means of rheological parameters $\left(\tau^{0}-\right.$ theoretical yield point $[\mathrm{Pa}], \mathrm{C}-$ consistency index $\left[\mathrm{Pa} \mathrm{s} \mathrm{s}^{\mathrm{P}}\right]$, $\mathrm{p}$ - and power exponent $[-])$ of different clotted custard sample groups

\begin{tabular}{lcrcr}
\hline Protein source & Sweetener & \multicolumn{1}{c}{$\tau_{0}(\mathrm{~Pa})$} & $\mathrm{C}\left(\mathrm{Pa} \mathrm{s}^{\mathrm{p}}\right)$ & $\mathrm{p}(-)$ \\
\hline Blood plasma & Sugar & $8.96 \pm 1.82$ & $4.78 \pm 0.29$ & $0.52 \pm 0.02$ \\
Blood plasma & Sweetener & $18.01 \pm 3.23$ & $8.68 \pm 0.86$ & $0.52 \pm 0.02$ \\
Milk & Sugar & $3.38 \pm 0.71$ & $1.68 \pm 0.14$ & $0.58 \pm 0.07$ \\
Milk & Sweetener & $5.11 \pm 1.66$ & $0.97 \pm 0.24$ & $0.61 \pm 0.10$ \\
\hline
\end{tabular}

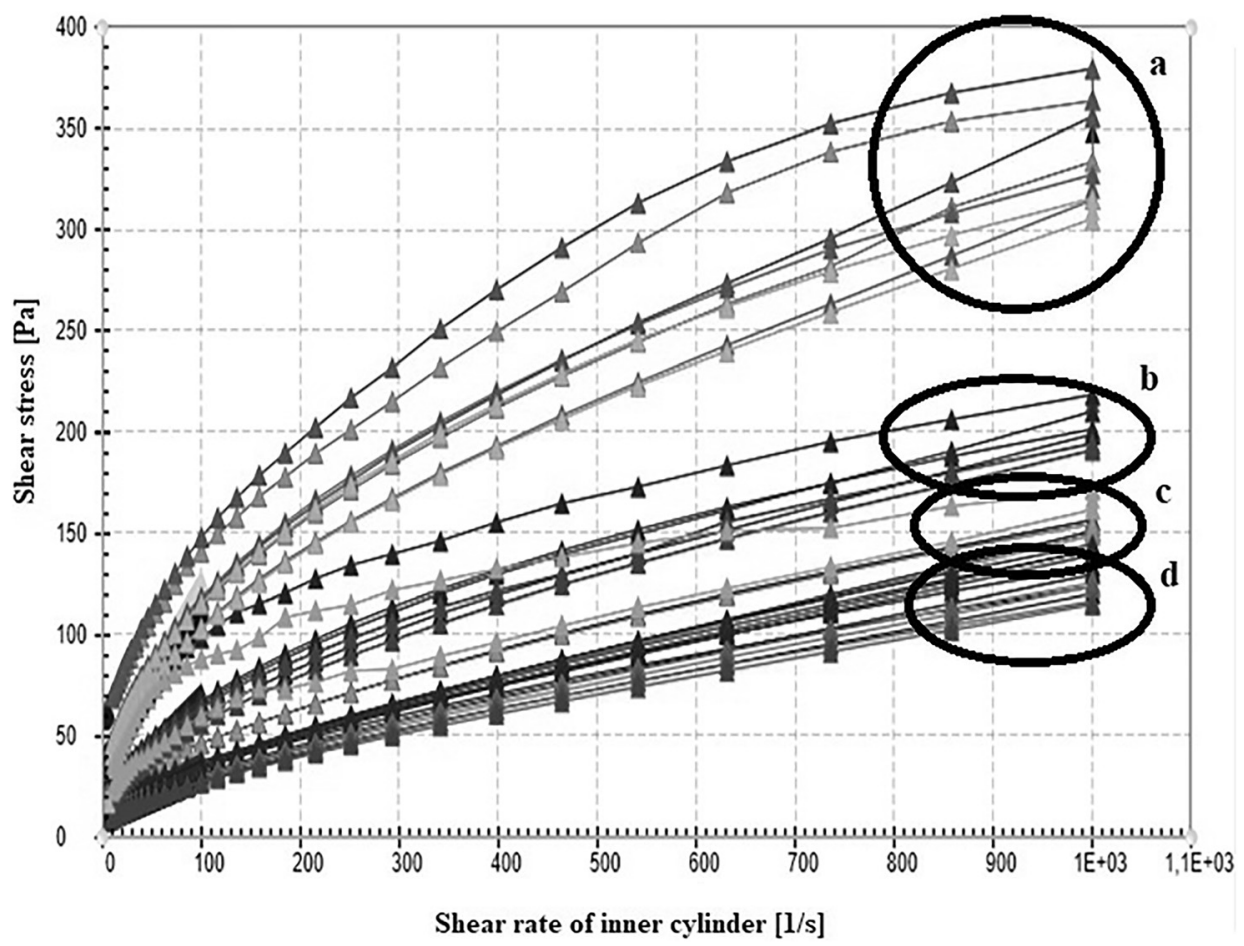

Fig. 1. Some flow curves of investigated sample groups (a - custards with blood plasma and sugar alcohols, b - custards with blood plasma and sugar, c - custards with milk and sugar, d - custards with milk and sugar alcohols) created by Anton Paar RheoCompass software 
course of flow curves were similar to results from the literature (González-Tomás et al., 2008; Vélez-Ruiz et al., 2005, 2006). In the case of blood plasma custards, the course of flow curves was similar but the theoretical yield point and the consistency index were a multiple of results of milk custards (Fig. 1).

\section{CONCLUSION}

Based on this research the allergenic milk can be substituted by non-allergenic blood plasma in simple food products like custard, but it causes a significant change in instrumentally measured sensory attributes. The used protein source as well as sweetener determine the colour, $\mathrm{pH}$ and texture of the final product. The caused colour change is clearly visible to the naked eye, but each sample was nearly white and another flavouring and/or colouring matter can mask this change. There is an important suggestion in the case of substituting milk protein by blood plasma protein: the used plasma concentrate or plasma powder should have reduced salt content because salt content of blood is high and it is concentrated in the plasma fraction. It causes considerable flavour change.

\section{ACKNOWLEDGEMENTS}

This research was supported by the Hungarian University of Agriculture and Life Sciences, Doctoral School of Food Sciences.

\section{REFERENCES}

Bassen, M.K., Gupta, L.K., Jolly, L., and Tewari, R.P. (1989). Thermal resistance of Bacillus cereus spores in custard preparations. MIRCEN Journal of Applied Microbiology and Biotechnology, 5(4): 511-516.

Caldironi, H.A. and Ockerman, H.W. (1982). Incorporation of blood proteins into sausage. Journal of Food Science, 47(2): 405-408.

Ceballos, L.S., Morales, E.R., de la Torre Adarve, G., Castro, J.D., Martínez, L.P., and Sampelayo, M.R.S. (2009). Composition of goat and cow milk produced under similar conditions and analyzed by identical methodology. Journal of food Composition and Analysis, 22(4): 322-329.

Commission Directive 98/15/EC of 27 February 1998 amending Council Directive 91/271/EEC with respect to certain requirements established in Annex I thereof.

Council Directive 91/271/EEC of 21 May 1991 concerning urban waste-water treatment.

Dawson, P.L. and Acton, J.C. (2018). Impact of proteins on food color. In Proteins in food processing (pp. 599-638). Woodhead Publishing.

De Cock, P. and Bechert, C.L. (2002). Erythritol. Functionality in noncaloric functional beverages. Pure and Applied Chemistry, 74(7): 1281-1289.

de Wijk, R.A., van Gemert, L.J., Terpstra, M.E., and Wilkinson, C.L. (2003). Texture of semi-solids; sensory and instrumental measurements on vanilla custard desserts. Food Quality and Preference, 14(4): 305317. 
Duarte, R.T., Carvalho Simões, M.C., and Sgarbieri, V.C. (1999). Bovine blood components: fractionation, composition, and nutritive value. Journal of Agricultural and Food Chemistry, 47(1): 231-236.

Goldman, A.S., Anderson, D.W., Sellers, W.A., Saperstein, S., Kniker, W.T., and Halpern, S.R. (1963). Milk allergy: I. Oral challenge with milk and isolated milk proteins in allergic children. Pediatrics, 32(3): 425443.

González-Tomás, L., Bayarri, S., Taylor, A.J., and Costell, E. (2008). Rheology, flavour release and perception of low-fat dairy desserts. International Dairy Journal, 18(8): 858-866.

Halliday, D. (1975). Blood-A source of proteins. Process Biochemistry, 10: 11-12.

Howell, N.K. and Lawrie, R.A. (1983). Functional aspects of blood plasma proteins. I. Separation and characterization. International Journal of Food Science \& Technology, 18(6): 747-762.

Hsieh, Y.H.P. and Ofori, J.A. (2011). Blood-derived products for human consumption. Revelation and Science, 1(01).

Kebede, G. and Ashenafi, M. (2010). Short CommunicationMicrobiological quality and safety of custard cakes from Addis Ababa. Ethiopian Journal of Biological Sciences, 9(2).

Melaja, A.J. and Hamalainen, L. (1977). U.S. Patent No. 4,008,285. Washington, DC: U.S. Patent and Trademark Office.

Mezger, T.G. (2006). The rheology handbook: for users of rotational and oscillatory rheometers. Vincentz Network GmbH \& Co KG.

O Salami, K., A Olorunlambe, A., O Adesina, B., F Akinwande, F., M Ahmed El-Imam, A., and A Oyeyinka, S. (2019). Physicochemical and sensory properties of corn starch custard soured with tamarind, soursop and lime. Hrvatski časopis za prehrambenu tehnologiju, biotehnologiju i nutricionizam, 14(3-4): 91-97.

Park, M., Moos, M., Young, I., MacDonald, C., and Meldrum, R. (2017). Microbiological quality of Portuguese custard tarts in Toronto-a pilot study. Environmental Health Review, 60(3): 73-76.

Raeker, M.Ö. and Johnson, L.A. (1995). Thermal and functional properties of bovine blood plasma and egg white proteins. Journal of Food Science, 60(4): 685-690.

Regulation (EC) No 1333/2008 of the European Parliament and of the Council of 16 December 2008 on food additives.

Regulation (EC) No 853/2004 of the European Parliament and of the Council of 29 April 2004 laying down specific hygiene rules for food of animal origin.

Spreer, E. (2017). Milk and dairy product technology. Routledge.

Tárrega, A., Izquierdo, L., and Costell, E. (2004). Scaling ranked data for correlating sensory and instrumental measures. Application to dairy desserts colour evaluation. 6th Pangborn Sensory Science Symposium, Yorkshire.

USDA, United States Department of Agriculture, Agricultural research service, Nutrient Data Laboratory. (2018). USDA National Nutrient Database for Standard Reference, Release 29. https://fdc.nal.usda.gov/.

Vélez-Ruiz, J.F., González-Tomás, L., and Costell, E. (2005). Rheology of dairy custard model systems: influence of milk-fat and hydrocolloid type. European Food Research and Technology, 221(3): 342-347.

Vélez-Ruiz, J., Hernando, I., González-Tomás, L., Pérez-Munuera, I., Quiles, A., Tárrega, A., Lluch, M.A., and Costell, E. (2006). Rheology and microstructure of custard model systems with cross-linked waxy maize starch. Flavour and Fragrance Journal, 21(1): 30-36.

Open Access. This is an open-access article distributed under the terms of the Creative Commons Attribution 4.0 International License (https://creativecommons.org/licenses/by/4.0/), which permits unrestricted use, distribution, and reproduction in any medium, provided the original author and source are credited, a link to the CC License is provided, and changes - if any - are indicated. (SID_1) 